\title{
No Cross Words for Materials
}

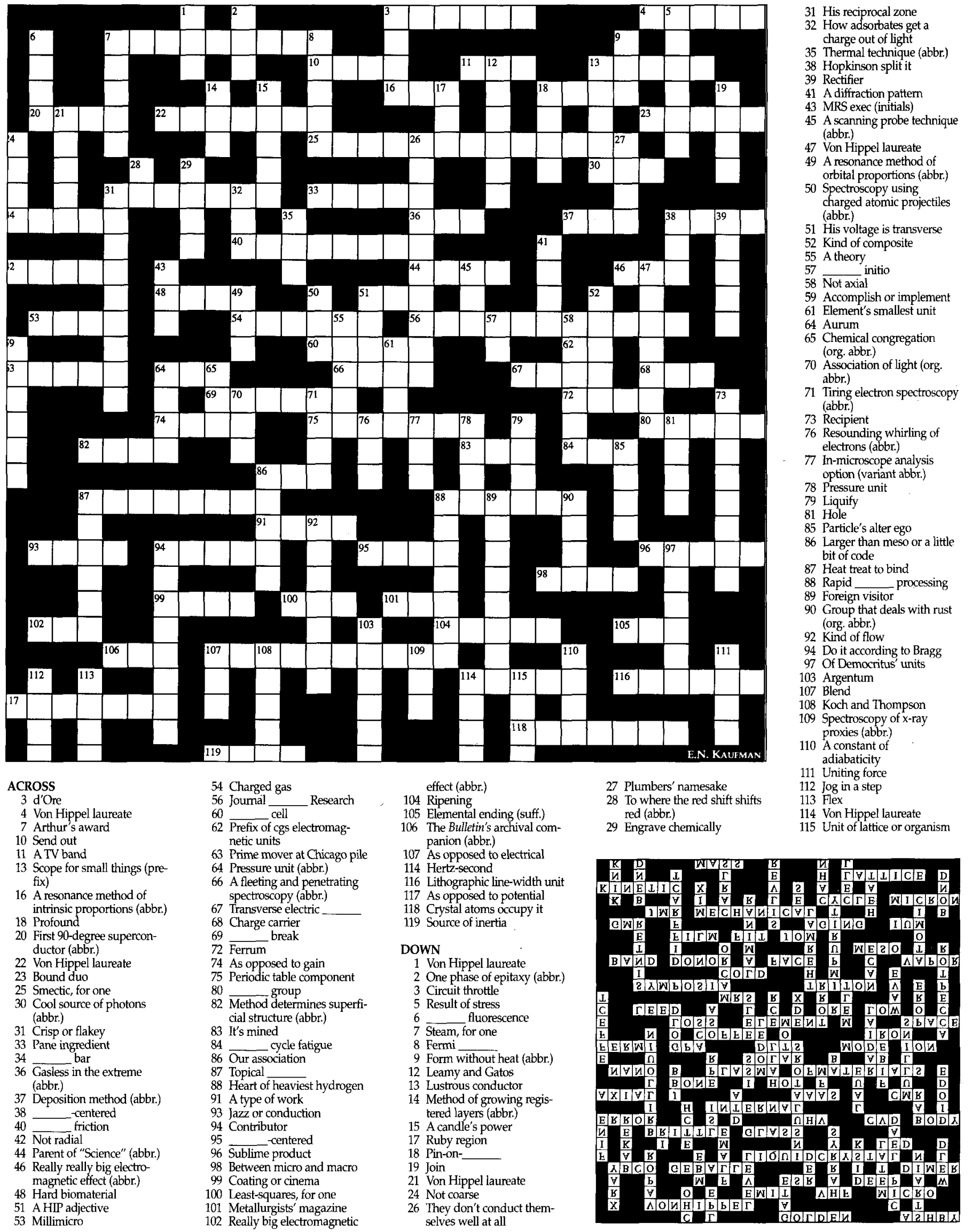

